ИСКУССТВОВЕДЕНИЕ

DOI: 10.17805/trudy.2015.5.8

\title{
СЕМАНТИКА НЕОПРЕДЕЛЕННОСТИ В РАССКАЗЕ А. П. ЧЕХОВА «ПОПРЫГУНЬЯ»
}

\author{
М. Б. Ясинская \\ (Московский гуманитарный университет)
}

Аннотация: В статье анализируются способы выражения семантики неопределённости в тексте рассказа А. П. Чехова «Попрыгунья»; определяется интенциональная направленность текста и восприятие его реципиентом.

Ключевые слова: А. П. Чехов; «Попрыгунья»; семантика; категория русского языка; русский язык; категория неопределенности; языковая картина мира

\section{THE SEMANTICS OF UNCERTAINTY IN A.P. CHEKHOV'S THE GRASSHOPPER}

\author{
M.B. Yasinskaya \\ (Moscow University for the Humanities)
}

Abstract: The article examines the means of expressing the semantics of uncertainty in A. P. Chekhov's short story The Grasshopper, with a special focus on the intentional aspect of the text and its perception by the recipient.

Keywords: A.P. Chekhov; The Grasshopper; semantics; category of Russian language; Russian language; category of uncertainty; linguistic world image

Семантическая категория определенности/неопределенности является одной из важнейших категорий русского языка; категория неопределенности считается семантической доминантой русской языковой картины мира (Арутюнова, 1995; Падучева, 1995; Колесов, 1999 и др.).

Под понятийной категорией определенности/неопределенности мы понимаем одну из категорий высказывания, функция которой, «ее - актуализация и детерминация имени, демонстрация его единственности в описываемой ситуации (определенность) либо выражение его отношения к классу подобных ему феноменов (неопределенность)» (Николаева, 1990: 376).

Семантика неопределенности наиболее явно репрезентирована 
неопределенными местоимениями (далее - НM). НМ исследованы с позиций описательной грамматики ${ }^{1}$, семантико-синтаксических особенностей ${ }^{2}$, когнитивистики ${ }^{3}$, как категории неопределенности ${ }^{4}$, функции в художественном тексте ${ }^{5}$.

Представляется интересным проанализировать семантический потенциал категории определенности/неопределенности в художественном тексте рассказа А. П. Чехова «Попрыгунья» (1892), выявить имплицитное коммуникативно-прагматическое намерение автора, моделирующее, на наш взгляд, референцию неопределенности в сознании реципиента.

Материалом для анализа послужили неопределенные местоимениясуществительные и местоимения-прилагательные (в тексте насчитывается свыше 50-ти употреблений) с аффиксами -то, -нибудь, не- и другие части речи, выполняющие дейктическую функцию в тексте рассказа.

Функция НМ в чеховском тексте не исчерпывается лишь обозначением неопределенности; НМ выполняют функцию организации художественного пространства текста, также являются средствами выражения и обозначения семантики неопределенности, что, в свою очередь, подразумевает у коммуникантов того или иного базиса понимания, помогающего декодировать коммуникативно-прагматические интенции автора.

В тексте можно выделить четыре семантических микрополя неопределенности: неизвестность, неясность, неполнота, неуверенность, организованных при помощи НМ, условно относящихся к планам выражения.

1. Семантическое микрополе неизвестности представлена следующими НМ- актуализаторами:

«Среди этой артистической, свободной и избалованной судьбою компании, правда, деликатной и скромной, но вспоминавшей о существовании каких-то докторов только во время болезни и для которой имя Дымов звучало так же различно, как Сидоров или Тарасов, - среди этой компании Дымов казался чужим, лишним и маленьким, хотя был высок ростом и широк в плечах» (Чехов, 1977: 8); «Ежедневно, вставши с постели часов в одиннадцать, Ольга Ивановна играла на рояли или же, если было солнце, писала что-нибудь масляными красками» (там же: 9); «На даче, очень неприглядной на вид, с низкими потолками, оклеенными писчею бумагой, и с неровными щелистыми полами, было только три комнаты. В одной стояла кровать, в другой на стульях и окнах валялись холсты, кисти, засаленная бумага и мужские пальто и шляпы, а в третьей Дымов застал трех каких-то незнакомых мужчин» (там же: 13); «Бирюзовый цвет воды, какого она раньше никогда не видала, небо, берега, черные тени и безотчетная (какая-то. - M. Я.) радость, наполнявшая ее душу, говорили ей, что из нее выйдет великая художница (какая-то. - М. Я.) и что где-то там за далью, за лунной ночью (где-то. - М. Я.), в бесконечном простран- 
стве (где-то. - М. Я.) ожидают ее успех, слава, любовь народа...» (там же: $15)$; «Ольга Ивановна сидела за перегородкой на кровати и, перебирая пальцами свои прекрасные льняные волосы, воображала себя то в гостиной, то в спальне, то в кабинете мужа; воображение уносило ее в театр, к портнихе и к знаменитым друзьям. Что-то они поделывают теперь?» (там же: 17); «Она уже не помнила ни лунного вечера на Волге, ни объяснений в любви, ни поэтической жизни в избе, а помнила только, что она из пустой прихоти, из баловства, вся, с руками и с ногами, вымазалась во что-то грязное, липкое, от чего никогда уж не отмоешься...» (там же: 28); «Молчаливое, безропотное, непонятное существо, обезличенное своею кротостью, бесхарактерное, слабое от излишней доброты, глухо страдало где-то там у себя на диване и не жаловалось» (там же: 28); «Nature morte, порт... - думала она, опять впадая в забытье, - спорт... курорт... А как Шрек? Шрек, грек, врек... крек. А где-то теперь мои друзья? Знают ли они, что у нас горе? Господи, спаси... избави. Шрек, грек...» (там же: 29) и др.

НМ семантического микрополя неизвестности обладают семантикой «абсолютной пространственной неопределенности» (ядро семантического микрополя неизвестности - «где-то там»), взаимодействующей с категорией субъективной модальности. С помощью НМ подчеркивается неспособность/нежелание/невозможность персонажей самоидентифицироваться и идентифицировать реальность, необходимость, возможность и т. п.;

2. Семантическое микрополе неясности эксплицирована НМ-актуализаторами:

«Ежедневно, вставши с постели часов в одиннадцать, Ольга Ивановна играла на рояли или же, если было солнце, писала что-нибудь масляными красками» (там же: 9); «Стоило кому-нибудь прославиться хоть немножко и заставить о себе говорить, как она уж знакомилась с ним (с кем-то. $-M$. Я.), в тот же день дружилась и приглашала к себе» (там же: 10); «Рядом с нею стоял Рябовский и говорил ей, что черные тени на воде - не тени, а сон (что-то. - M. Я.), что в виду этой колдовской воды с фантастическим блеском, в виду бездонного неба и грустных, задумчивых берегов, говорящих о суете нашей жизни и о существовании чего-то высшего, вечного, блаженного, хорошо бы забыться, умереть, стать воспоминанием (там же: 15); «Как вам не наскучит? Я бы на вашем месте бросил живопись и занялся серьезно музыкой или чем-нибудь» (там же: 25); «Но, напившись кофе, она соображала, что Рябовский отнял у нее мужа и что теперь она осталась без мужа и без Рябовского; потом она вспоминала разговоры своих знакомых о том, что Рябовский готовит к выставке нечто (что-то. - М. Я.) поразительное, смесь пейзажа с жанром (что-то. - М. Я.), во вкусе Поленова, отчего все (кто-то. - М. Я.), кто бывает в его мастерской, при- 
ходят в восторг; но ведь это, думала она, он создал под ее влиянием и вообще, благодаря ее влиянию, он сильно изменился к лучшему» (там же: 22); «И вспоминала она также, что в последний раз он приходил к ней в каком-то сером сюртучке с искрами и в новом галстуке и спрашивал томно: «Я красив?» (там же: 22); «По-прежнему она каждый день возвращалась поздно ночью, но Дымов уже не спал, как в прошлом году, а сидел у себя в кабинете и что-то работал» (там же: 24) и др.

Коммуникативный потенциал персонажей выражает отношение «внутреннего видения» и «внешнего», существующего в субъективной модальности семантики неясности, размытости, нечеткости, зыбкости (ядро семантического микрополя «что-то/кто-то»), не позволяющей объективно оценить субъектно-объектную референцию к действительности;

3. Семантическое микрополе неполноты актуализирована НМ:

«А между тем Ольга Ивановна и ее друзья и добрые знакомые были не совсем обыкновенные люди. Каждый из них был чем-нибудь замечателен и немножко (сколько-то. - $M$. Я.) известен, имел уже имя и считался знаменитостью, или же хотя и не был еще знаменит, но зато подавал блестящие надежды» (там же: 7); «Почти каждый день к ней приходил Рябовский, чтобы посмотреть, какие она сделала успехи по живописи. Когда она показывала ему свою живопись, он засовывал руки глубоко в карманы, крепко сжимал губы, сопел и говорил: Так-с... Это облако у вас кричит: оно освещено не по-вечернему. Передний план как-то сжеван, и что-то, понимаете ли, не то... А избушка у вас подавилась чем-то и жалобно пищит... надо бы угол этот потемнее (как-то. - М. Я.) взять. А в общем недурственно (как-то. - М. Я.)... Хвалю» (там же: 12); «Она вдруг почувствовала себя оскорбленной и сказала холодно: Нам нужно расстаться на некоторое время, а то от скуки мы можем серьезно поссориться. Мне это надоело. Сегодня я уеду» (там же: 20) и др.

НM, актуализирующие семантику неполноты, выражают семантику недостаточности, несоотнесенности участников действия с участниками речевого акта; некую недоговоренность, недосказанность, отраженную в субъективной модальности без идентифицирующих референций, которые не входят в пресуппозицию коммуникантов и автокоммуникантов (ядро семантического микрополя «как-то»-«немножко»);

4. Семантическое микрополе неуверенности выражено НМ:

«- Посмотрите на него: не правда ли, в нем что-то есть? - говорила она своим друзьям, кивая на мужа и как бы желая объяснить, почему это она вышла за простого, очень обыкновенного и ничем не замечательного человека» (там же: 7); «Не правда ли, в нем есть что-то сильное, могучее, медвежье?» (там же: 8); «Ни одна вечеринка не обходилась без того, чтобы хозяйка не вздрагивала при каждом звонке и не говорила с победным выражением лица: «Это он!», разумея под словом «он» какую-нибудь но- 
вую приглашенную знаменитость» (там же: 11); «Рябовский схватил себя за голову и прошелся из угла в угол, потом с решительным лицом, как будто желая что-то кому-то доказать, надел фуражку, перекинул через плечо ружье и вышел из избы» (там же: 19); «Однажды она сказала Рябовскому про мужа: «Этот человек (кто-то. - М. Я.) гнетет меня своим великодушием!» Эта фраза ей так понравилась, что, встречаясь с художниками, которые знали об ее романе с Рябовским, она всякий раз говорила про мужа, делая энергический жест рукой: «Этот человек гнетет меня своим великодушием!» (там же: 23); «Ольге Ивановне хотелось громко крикнуть, ударить художника по голове чем-нибудь тяжелым и уйти, но она ничего не видела сквозь слезы, была подавлена своим стыдом и чувствовала себя уж не Ольгой Ивановной и не художницей (кем-то. - М. Я.), а маленькою козявкой (кем-то. - М. Я.)» (там же: 25); «Один из докторов нечаянно чемуто засмеялся, и как-то странно и робко прозвучал этот смех, даже жутко сделалось» (там же: 29) и др.

Семантическое микрополе неуверенности является реперной точкой семантического поля неопределенности всего текста. Ср.: «Не правда ли, в нем (Дымове. - М. Я.) есть что-то сильное, могучее, медвежье?» (там же: 8); «Ты один только можешь спасти меня! Завтра будет здесь преоригинальная свадьба, - продолжала она, смеясь и завязывая мужу галстук. - Женится молодой телеграфист на станции, некто Чикельдеев. <...> Красивый молодой человек, ну, неглупый, и есть в лице, знаешь, что-то сильное, медвежье... (там же: 14).

В семантическом микрополе неуверенности явлена попытка коммуникантов самоидентифицироваться и идентифицироваться в континууме: личность - неличность, реальность - гипотетичность реальности ирреальность.

Семантика неуверенности реализуется как модальность, как категория отношения связи мира внешних явлений и внутреннего мира человека, как отношение высказывания субъекта к действительности (ядро семантического микрополя неуверенности «что-то кому-то»).

НМ «что-то - кому-то» является ядром в семантическом поле неопределенности, организуют весь текст, актуализируя семантику неуверенности, неполноты, неясности и неизвестности.

НМ «что-то» - «кто-то» - «кому-то» - «как-то»- «немножко» - «2де-то» - «там» можно назвать интенсификаторами смысла текста рассказа А. П. Чехова «Попрыгунья»; интенсификаторы смысла устанавливают имплицитные отношения между элементами художественного текста.

Таким образом, главная героиня «попрыгунья» занимается «чемнибудь», пишет «что-нибудь», ощущает себя «не художницей», а «козявкой», и попадает во «что-то грязное, липкое»; окружают ее - муж, в кото- 
ром «что-то есть», он - «Сидоров», «Тарасов», «Чикильдеев», «существо» и «этот человек», который «что-то работал»; любовник - «в каком-то сером сюртучке», «некто», пишущий «нечто поразительное»; знакомые - «какие-то доктора», «кто-то», и они «что-то поделывают», находятся «где-то», и в целом жизнь - «где-то там», «в некотором времени» и похожа на «этюд», «nature morte».

Представляется, что НМ выполняют функцию не только актуализации семантического выражения неопределенности, но и функцию экономии языковых средств выражения; также являются одновременно формальными маркерами авторского отношения и интерпретаторами его содержания.

Семантика неопределенности, актуализированная НM, является текстообразующей сущностью, выраженной посредством авторской модальности, позволяет декодировать имплицитные смыслы коммуникативнопрагматической интенции писателя, направленной на моделирование пространства неопределенности как художественного средства воздействия на реципиента.

\section{СПИСОК ЛИТЕРАТУРЫ}

Арутюнова, Н. Д. (1995) Логический анализ языка: Истина и истинность в контексте разных культур. М.: Языки славянской культуры.

Колесов, В. В. (2006) Русская ментальность в языке и тексте. СПб.: Петербургское востоковедение.

Николаева, Т. М. (1990) Определённости/неопределённости категория // Лингвистический энциклопедический словарь / глав. ред. В. Н. Ярцева. М. : Наука. С. 376.

Падучева, Е. В. (1996) Семантические исследования. Семантика времени и вида в русском языке. Семантика нарратива. Изд. 2-е. М.: Языки славянской культуры.

Чехов, А. П. (1977) Попрыгунья // Чехов А. П. Полное собрание сочинений и писем : в 30 т. Сочинения : в 18 т. М. : Наука. Т. 8. С. 7-31.

Ясинская Милена Борисовна - кандидат филологических наук, доцент, профессор кафедры философии, политологии и культурологии Московского гуманитарного университета. Адрес: 111395, Россия, г. Москва, ул. Юности, д. 5. Тел.: +7 (499) 374-55-11. Эл. адрес: yassinska@gmail.com

Yasinskaya Milena Borisovna, Candidate of Philology, Professor, Department of philosophy, culturology and politology, Moscow University for the Humanities. Postal address: 5 Yunosti St., 111395 Moscow, Russian Federation. Tel.+7 (499) 374-55-11.E-mail: yassinska@gmail.com 


\section{ПРИМЕЧАНИЯ}

${ }^{1}$ Изучение сходства и различия значений НM, имеющих разные аффиксы, зависимость их значений от наличия информации у говорящего (М. В. Ломоносов, Н.И.Греч, Г. П. Павский, И. И. Давыдов, Ф. И. Буслаев).

${ }^{2}$ Работы А. А. Шахматова, В. В. Виноградова, А. М. Пешковского.

${ }^{3}$ В когнитивном аспекте все русские местоимения делят на две группы: 1) местоимения, которые совмещают функцию указания с функцией обозначения некоторых категорий бытия; 2) местоимения, модифицирующие смыслы, и выражающие категорию определенности/неопределенности (Н. Ю. Шведова).

${ }^{4}$ В работах Е. М. Галкиной-Федорук, Т. М. Николаевой, Е. В. Падучевой, А. Д. Шмелева и др.

${ }^{5}$ В работах И. И. Ковтуновой, Н.А. Кожевниковой, Л. А. Горшкова.

${ }^{6}$ Под ядром семантического микрополя мы понимаем смысло- и текстообразующий фактор художественного пространства текста. 